\title{
Uji Amelioran Organik Asal Limbah Pertanian pada Pertanaman Sawi Hijau (Brassica juncea L.) di Tanah Gambut
}

\section{Evaluation of Organic Ameliorant from Agricultural Waste on Green Mustard (Brassica juncea L.) Grown in Peat Soil}

\author{
Armiyarsih $^{1 *}$, Iwan Sasli ${ }^{2}$, dan Tris Haris Ramadhan ${ }^{2}$ \\ ${ }^{1}$ Program Studi Agroteknologi, Fakultas Pertanian, Universitas Tanjungpura \\ ${ }^{2}$ Jurusan Budidaya Pertanian, Universitas Tanjungpura \\ Jl. Prof. Dr. H. Hadari Nawawi Pontianak 78124, Indonesia
}

Diterima 22 Oktober 2020/Disetujui 30 November 2020

\begin{abstract}
The use of agricultural waste as an organic ameliorant can reduce the dependence on the use of synthetic chemical fertilizers on the cultivation of mustard on peat soils. The research objective was to determine the best effect of the compost dosage of oil palm empty bunches (TKKS) and banana trunk waste on the growth and yield of mustard in peat soil. The location of the study was located in Baning Village, Sintang District, from April to June 2020. The research used a factorial completely randomized design. The first factor is the usage of 5 compost levels of TKKS which are $t_{0}$ (without compost), $t_{1}\left(5\right.$ tons $\left.h a^{-1}\right), t_{2}\left(10\right.$ tons $\left.h a^{-1}\right), t_{3}\left(15\right.$ tons $\left.h a^{-1}\right), t_{4}\left(20\right.$ tons $\left.h a^{-1}\right)$. The second factor was the dosage of banana trunk compost with 4 levels of $p_{0}$ (without compost), $p_{1}\left(10\right.$ tons $\left.\mathrm{ha}^{-1}\right), p_{2}\left(20\right.$ tons ha $\left.{ }^{-1}\right), p_{3}\left(30\right.$ tons ha $\left.{ }^{-1}\right)$. Treatment interactions significantly increased plant height, leaf number, leaf area, plant fresh weight, plant dry weight, net assimilation rate, and plant growth rate. The N, P, and K content in the soil increased by a percentage of $53.85 \%, 409.90 \%$, and 2,709\% on the application of 15 tons $h a^{-1}$ TKKS compost +30 tons $h a^{-1}$ banana trunk and compost. This treatment combination was the best in this study for increasing the production of mustard greens in peat soil, indicated by the average of plant fresh weight of $176.71 \mathrm{~g}$.
\end{abstract}

Keywords: banana trunk, crop production, oil palm empty bunches

\section{ABSTRAK}

Penggunaan limbah pertanian sebagai bahan amelioran organik dapat mengurangi ketergantungan penggunaan pupuk kimia sintetik pada budidaya tanaman sawi hijau di tanah gambut. Tujuan penelitian untuk mengetahui pengaruh dosis kompos limbah tandan kosong kelapa sawit (TKKS) dan gedebok pisang terbaik terhadap pertumbuhan dan hasil sawi hijau di tanah gambut. Lokasi penelitian bertempat di Desa Baning Kota, Kabupaten Sintang pada bulan April sampai dengan Juni 2020. Penelitian menggunakan rancangan acak lengkap faktorial. Faktor pertama yaitu pemberian dosis kompos TKKS 5 taraf $t_{0}$ (tanpa kompos), $t_{1}(5$ ton ha-1 $), t_{2}\left(10\right.$ ton ha $\left.{ }^{-1}\right), t_{3}\left(15\right.$ ton ha- $\left.{ }^{-1}\right)$, dan $t_{4}\left(20\right.$ ton ha- $\left.{ }^{-1}\right)$. Faktor kedua yaitu dosis kompos gedebok pisang dengan 4 taraf $p_{0}$ (tanpa kompos), $p_{1}\left(10\right.$ ton ha $\left.{ }^{-1}\right), p_{2}\left(20\right.$ ton ha $\left.a^{-1}\right)$, dan $p_{3}\left(30\right.$ ton ha- ${ }^{-1}$ ). Interaksi perlakuan secara signifikan dapat meningkatkan tinggi tanaman, jumlah daun, luas daun, bobot segar tanaman, bobot kering tanaman, laju asimilasi bersih, dan laju pertumbuhan tanaman. Kandungan N, $P$, dan $K$ di tanah meningkat $53.85 \%, 409.90 \%$ dan 2,709\% pada pemberian 15 ton ha ${ }^{-1}$ kompos TKKS +30 ton ha ${ }^{-1}$ kompos gedebok pisang. Kombinasi perlakuan ini adalah yang terbaik dalam penelitian ini untuk meningkatkan produksi sawi hijau di tanah gambut, ditunjukkan dengan rata-rata bobot segar tanaman sebesar $176.71 \mathrm{~g}$.

Kata kunci: gedebok pisang, produksi tanaman, tandan kosong kelapa sawit

\section{PENDAHULUAN}

Sawi hijau (Brassica juncea L.) merupakan tanaman hortikultura yang banyak digemari oleh masyarakat, karena banyak mengandung protein, vitamin, serat, air, dan

\footnotetext{
* Penulis untuk korespondensi. e-mail: armi_yarsih@yahoo.com
}

karbohidrat (Direktorat Gizi, Depkes RI, 2012), sehingga sangat baik untuk dibudidayakan dan dikembangkan oleh petani. Produksi sawi pada tahun 2017 sebanyak 34,098 ton dan tahun 2018 sebanyak 29,610 ton, atau ada penurunan sebesar 4,488 ton atau turun sebesar 13.16\% (Badan Pusat Statistik, 2018a).

Sebagian besar tanaman hortikultura di Kalimantan Barat dibudidayakan di tanah gambut. Secara alamiah 
tanah gambut yang digunakan untuk kegiatan budidaya dihadapkan pada kendala tingginya kandungan asam organik yang menjadi penyebab rendahnya $\mathrm{pH}$, kurang baiknya sifat fisik, kimia dan biologi sehingga unsur hara tidak tersedia bagi tanaman (Riswandi, 2011). Luas tanah gambut di Kalimantan Barat mencapai 1.54 juta ha (Badan Pusat Statistik, 2018b), sehingga sangat berpotensi digunakan sebagai media tumbuh dalam meningkatkan produksi sawi hijau dengan upaya perbaikan lahan budidaya dengan memanfaatkan limbah pertanian sebagai bahan amelioran.

Limbah tandan kosong kelapa sawit (TKKS) dan gedebok pisang dapat dimanfaatkan sebagai sumber energi dan pupuk organik. Pengolahan limbah TKKS dan gedebok pisang menjadi kompos merupakan alternatif terbaik yang dapat dilakukan dalam mengurangi limbah pertanian, mengurangipenggunaan pupuk kimia, dan ramahlingkungan, dalam meningkatkan kesuburan tanah. Penerapan teknologi LEISA (Low External Input for Sustainable Agriculture) dalam kegiatan budidaya sawi hijau pada tanah gambut dapat dicapai dengan menggunakan amelioran organik berupa kompos. Limbah gedebok pisang sebagai dekomposer atau bioaktivator dapat dipadukan dengan TKKS pada proses pengomposan. Tujuan penelitian yaitu untuk mengetahui dosis terbaik kompos limbah TKKS dan kompos gedebok pisang pada sawi hijau di tanah gambut.

\section{BAHAN DAN METODE}

Penelitian dilakukan di Desa Baning Kota, Kabupaten Sintang, pada bulan April sampai Juni 2020. Metode penelitian disusun dalam bentuk rancangan acak lengkap faktorial dengan 2 faktor. Faktor pertama yaitu pemberian berbagai dosis kompos TKKS dengan 5 taraf yaitu $\mathrm{t}_{0}=$ tanpa kompos, $\mathrm{t}_{1}=60 \mathrm{~g}$ per polibag $\approx 5$ ton $\mathrm{ha}^{-1}, \mathrm{t}_{2}=120$ $\mathrm{g}$ per polibag $\approx 10$ ton $\mathrm{ha}^{-1}, \mathrm{t}_{3}=180 \mathrm{~g}$ per polibag $\approx 15$ ton $\mathrm{ha}^{-1}, \mathrm{t}_{4}=240 \mathrm{~g}$ per polibag $\approx 20$ ton $\mathrm{ha}^{-1}$. Faktor kedua yaitu pemberian berbagai dosis kompos gedebok pisang dengan 4 taraf yaitu $\mathrm{p}_{0}=$ tanpa kompos, $\mathrm{p}_{1}=120 \mathrm{~g}$ per polibag $\approx 10$ ton $\mathrm{ha}^{-1}, \mathrm{p}_{2}=240 \mathrm{~g}$ per polibag $\approx 20$ ton $\mathrm{ha}^{-1}, \mathrm{p}_{3}=360 \mathrm{~g}$ per polibag $\approx 30$ ton $\mathrm{ha}^{-1}$.

Tanah gambut yang diambil dari kedalaman 0-20 cm dibersihkan dari serasah kasar kemudian dikering anginkan. Tanah gambut sebanyak $2.5 \mathrm{~kg}$ selanjutnya dimasukkan ke dalam polibag dengan ukuran $20 \mathrm{~cm}$ x $40 \mathrm{~cm}$, kemudian dicampurkan dengan kompos TKKS dan kompos gedebok pisang sesuai dosis perlakuan dan diinkubasi selama 2 minggu. Bibit sawi hijau yang telah memiliki empat helai daun sempurna kemudian dipindahkan ke dalam media tanam yang telah diinkubasi selama 2 minggu sebanyak satu bibit per polibag. Perawatan tanaman yang dilakukan meliputi penyiraman pada pagi hari pukul 06.00 WIB dengan air hujan sebanyak $300 \mathrm{~mL}$ per polibag, penyiangan gulma dan pengendalian hama penyakit dengan pemanfaatan tanaman refugia. Panen sawi hijau dilakukan saat tanaman berumur 45 hari setelah tanam dengan ciri-ciri daun telah lebar, berwarna hijau tua, daun pertama sudah mulai menua dan terlihat gejala menguning.
Pengamatan karakter agronomi meliputi tinggi tanaman 1, 2, 3, 4, dan 5 minggu setelah tanam (MST) dan saat panen antara lain jumlah daun, bobot segar tanaman, bobot kering tanaman di oven dengan suhu $105^{\circ} \mathrm{C}$ selama 24 jam, luas daun, laju asimilasi bersih dan laju pertumbuhan tanaman menggunakan rumus berikut:

$$
\begin{aligned}
& \mathrm{LAB}=\frac{\mathrm{W}_{2}-\mathrm{W}_{1}}{\mathrm{~T}_{2}-\mathrm{T}_{1}} x \frac{\ln . \mathrm{LD}_{2}-\ln . \mathrm{LD}_{1}}{\mathrm{LD}_{2}-\mathrm{LD}_{1}} \\
& \mathrm{LPT}=\frac{1}{\mathrm{LT}} x \frac{\left(\mathrm{W}_{2}-\mathrm{W}_{1}\right)}{\left(\mathrm{T}_{2}-\mathrm{T}_{1}\right)}=\frac{\left(\mathrm{W}_{2}-\mathrm{W}_{1}\right)}{\mathrm{LT}\left(\mathrm{T}_{2}-\mathrm{T}_{1}\right)}
\end{aligned}
$$

Keterangan:

LAB $=$ Laju Asimilasi Bersih, LPT = Laju Pertumbuhan Tanaman, $\mathrm{W}_{1}$ dan $\mathrm{W}_{2}=$ Bobot kering tanaman pengamatan ke-1 dan ke-2, $\mathrm{LD}_{1}$ dan $\mathrm{LD}_{2}=$ Luas daun tanaman pengamatan ke-1 dan ke-2, $\mathrm{T}_{1}$ dan $\mathrm{T}_{2}=$ Waktu Pengamatan ke-1 dan ke-2, LT = Luas tanah (jarak tanam).

Data hasil pengukuran ditabulasi dan dianalisis menggunakan analisis keragaman (anova) dilanjutkan dengan uji BNJ taraf 5\%.

\section{HASIL DAN PEMBAHASAN}

\section{Tinggi Tanaman}

Hasil analisis keragaman menunjukkan bahwa dosis interaksi TKKS dan kompos gedebok pisang berpengaruh nyata terhadap tinggi tanaman sawi hijau. Rata-rata tinggi tanaman sawi hijau pada setiap periode pengamatan dapat dilihat pada Gambar 1. Tinggi tanaman sawi hijau terbaik

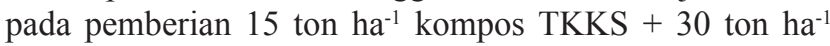
kompos gedebok pisang minggu ke-6 dengan rata-rata $37.86 \mathrm{~cm}$ dan tinggi tanaman terendah yaitu pada perlakuan tanpa pemberian kompos dengan rata-rata $9.52 \mathrm{~cm}$. Meningkatnya dosis kompos yang diaplikasikan kedalam tanah gambut, menyebabkan akumulasi nitrogen semakin meningkat dan proses metabolisme tanaman akan berjalan dengan optimal. Menurut Hasanudin (2003) asam amino yang dihasilkan akibat dekomposisi bahan organik di dalam tanah akan terurai menjadi ammonium $\left(\mathrm{NH}_{4}^{+}\right)$atau nitrat $\left(\mathrm{NO}_{3}^{-}\right)$sehingga dapat menyumbang ketersediaan nitrogen yang berfungsi untuk penambahan tinggi tanaman. Proses pembelahan dan pembesaran sel yang menyebabkan daun muda lebih cepat mencapai bentuk yang sempurna jika terdapat unsur N, P dan K pada media tanam (Leonardo et al., 2016).

\section{Jumlah Daun}

Hasil analisis keragaman menunjukkan bahwa dosis interaksi TKKS dan gedebok pisang berpengaruh nyata terhadap jumlah daun. Rata-rata jumlah daun sawi hijau dapat dilihat pada Tabel 1. Jumlah daun terbaik diperoleh pada pemberian 15 ton ha ${ }^{-1}$ kompos TKKS +30 ton ha- 

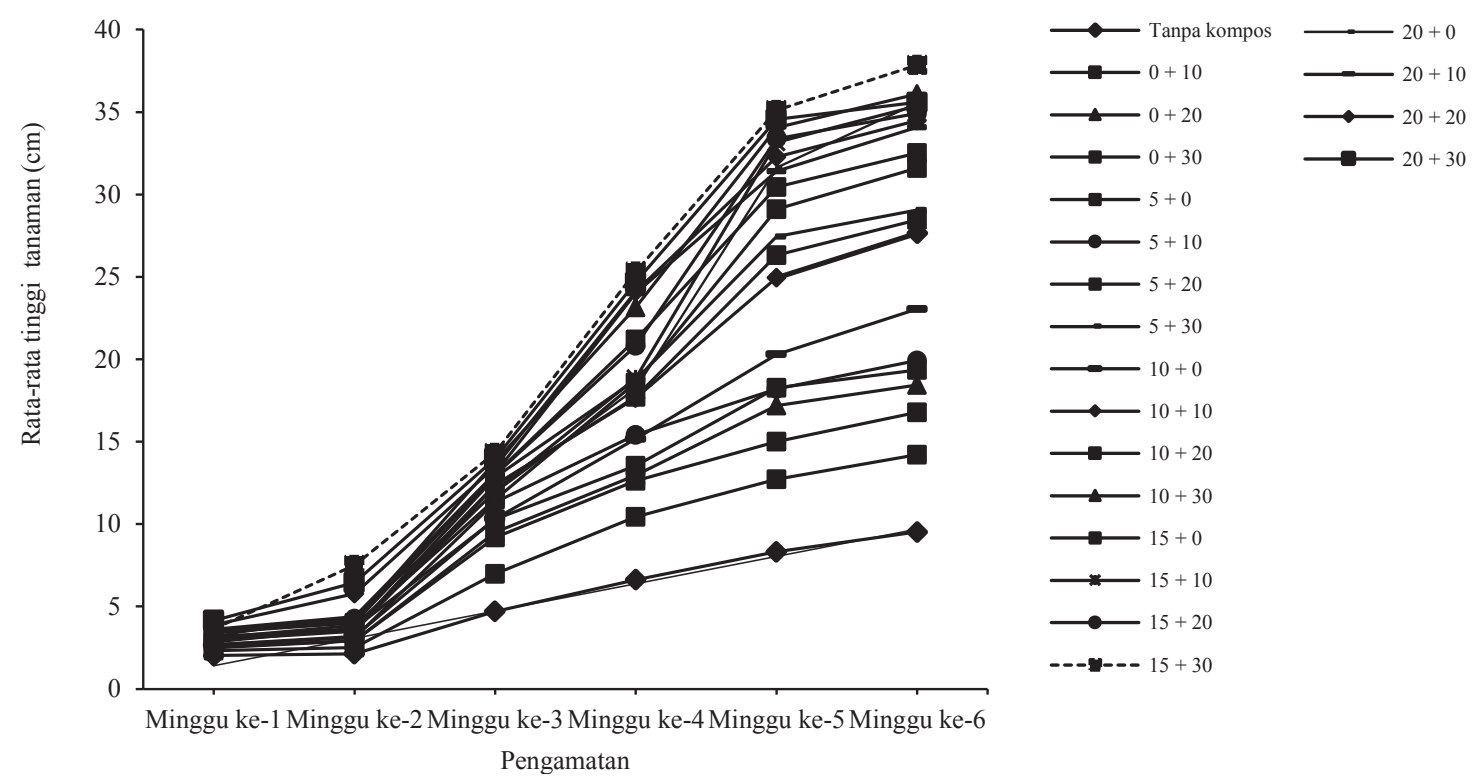

Gambar 1. Rata-rata tinggi tanaman sawi hijau pada tanah gambut dengan pemberian berbagai dosis kombinasi kompos TKKS dan kompos gedebok pisang

Tabel 1. Rata-rata jumlah daun, luas daun, bobot segar tanaman dan bobot kering tanaman pada berbagai dosis kombinasi kompos TKKS dan kompos gedebok pisang

\begin{tabular}{lcccc}
\hline $\begin{array}{l}\text { Dosis kompos TKKS } \\
+ \text { gedebok pisang } \\
\left(\text { ton ha- }{ }^{-1}\right)\end{array}$ & $\begin{array}{c}\text { Rata-rata jumlah daun } \\
\text { (helai) }\end{array}$ & $\begin{array}{c}\text { Rata-rata luas daun } \\
\left(\mathrm{cm}^{2}\right)\end{array}$ & $\begin{array}{c}\text { Rata-rata bobot segar } \\
\text { tanaman } \\
(\mathrm{g})\end{array}$ & $\begin{array}{c}\text { Rata-rata bobot kering } \\
\text { tanaman } \\
(\mathrm{g})\end{array}$ \\
\hline Tanpa kompos & $5.22 \mathrm{a}$ & $15.70 \mathrm{a}$ & $9.52 \mathrm{a}$ & $1.09 \mathrm{a}$ \\
$0+10$ & $6.00 \mathrm{~b}$ & $69.33 \mathrm{~b}$ & $24.64 \mathrm{~b}$ & $2.80 \mathrm{~b}$ \\
$0+20$ & $6.78 \mathrm{c}$ & $83.95 \mathrm{~b}$ & $64.61 \mathrm{c}$ & $5.84 \mathrm{c}$ \\
$0+30$ & $7.22 \mathrm{c}$ & $166.86 \mathrm{c}$ & $66.86 \mathrm{c}$ & $6.07 \mathrm{c}$ \\
$5+0$ & $5.56 \mathrm{ab}$ & $75.52 \mathrm{~b}$ & $22.18 \mathrm{~b}$ & $2.13 \mathrm{a}$ \\
$5+10$ & $9.11 \mathrm{~d}$ & $156.88 \mathrm{c}$ & $62.86 \mathrm{c}$ & $5.54 \mathrm{c}$ \\
$5+20$ & $10.78 \mathrm{hi}$ & $241.04 \mathrm{~d}$ & $97.14 \mathrm{e}$ & $9.11 \mathrm{~d}$ \\
$5+30$ & $11.78 \mathrm{j}$ & $259.23 \mathrm{de}$ & $108.64 \mathrm{fg}$ & $9.02 \mathrm{~d}$ \\
$10+0$ & $9.00 \mathrm{~d}$ & $191.42 \mathrm{c}$ & $83.66 \mathrm{~d}$ & $8.53 \mathrm{~d}$ \\
$10+10$ & $9.22 \mathrm{de}$ & $290.89 \mathrm{efg}$ & $95.36 \mathrm{e}$ & $9.10 \mathrm{~d}$ \\
$10+20$ & $9.89 \mathrm{efg}$ & $328.27 \mathrm{ghij}$ & $121.26 \mathrm{~h}$ & $11.14 \mathrm{e}$ \\
$10+30$ & $11.33 \mathrm{ij}$ & $353.99 \mathrm{jk}$ & $129.21 \mathrm{i}$ & $11.23 \mathrm{e}$ \\
$15+0$ & $10.44 \mathrm{gh}$ & $272.01 \mathrm{def}$ & $115.62 \mathrm{gh}$ & $11.05 \mathrm{e}$ \\
$15+10$ & $10.00 \mathrm{fg}$ & $298.51 \mathrm{fgh}$ & $130.87 \mathrm{i}$ & $13.17 \mathrm{fg}$ \\
$15+20$ & $11.44 \mathrm{ij}$ & $339.68 \mathrm{ijk}$ & $142.70 \mathrm{jk}$ & $13.98 \mathrm{gh}$ \\
$15+30$ & $13.00 \mathrm{k}$ & 400.741 & 176.711 & $16.80 \mathrm{i}$ \\
$20+0$ & $9.67 \mathrm{def}$ & $304.55 \mathrm{fghi}$ & $107.56 \mathrm{f}$ & $10.42 \mathrm{e}$ \\
$20+10$ & $9.44 \mathrm{def}$ & $304.40 \mathrm{fghi}$ & $117.23 \mathrm{~h}$ & $12.66 \mathrm{f}$ \\
$20+20$ & $10.78 \mathrm{hi}$ & $368.57 \mathrm{kl}$ & $137.96 \mathrm{j}$ & $14.67 \mathrm{~h}$ \\
$20+30$ & $11.67 \mathrm{j}$ & $329.74 \mathrm{hij}$ & $145.86 \mathrm{k}$ & $14.65 \mathrm{~h}$ \\
\hline BNJ $5 \%$ & 0.68 & 38.21 & 7.02 & 1.14 \\
\hline
\end{tabular}

Keterangan: Angka yang diikuti huruf yang sama pada kolom yang sama tidak berbeda nyata berdasarkan uji BNJ pada $\alpha=5 \%$ 
kompos gedebok pisang dengan rata-rata 13.00 helai yang berbeda nyata dengan jumlah daun pada perlakuan lainnya, sedangkan jumlah daun terendah diperolah pada perlakuan tanpa pemberian kompos dengan rata-rata 5.22 helai yang berbeda tidak nyata dengan jumlah daun pada permberian 5 ton ha $^{-1}$ kompos TKKS +0 ton ha ${ }^{-1}$ kompos gedebok pisang namun berbeda nyata dengan perlakuan lainnya. Peningkatan dosis kompos TKKS dan gedebok pisang yang diaplikasikan ke dalam tanah gambut berdampak pada peningkatan $\mathrm{pH}$ tanah sehingga ketersediaan unsur hara bagi tanaman dapat semakin meningkat. Menurut Pane et al., (2014) tanah yang diaplikasikan bahan organik dapat meningkatkan kapasitas tukar kation dan meningkatkan $\mathrm{pH}$ tanah. Sari et al., (2015) menambahkan bahwa peningkatan $\mathrm{pH}$ tanah merupakan indikator dari membaiknya sifat kimia tanah yaitu dalam penyediaan unsur hara bagi tanaman. selain itu, pemberian kompos TKKS dan kompos gedebok pisang yang mengandung $\mathrm{N}$ masing-masing $2.36 \%$ TKKS dan $2.12 \%$ gedebok pisang dapat meningkatkan penyerapan $\mathrm{N}$ oleh tanaman dalam bentuk nitrat dan ammonium. Menurut Fauzi dan Puspita (2017) N merupakan unsur hara yang berperan dalam menyusun protein dan klorofil sehingga dapat membantu tanaman dalam proses pembentukan daun.

\section{Luas Daun}

Hasil analisis keragaman menunjukkan bahwa dosis interaksi kompos TKKS dan kompos gedebok pisang berpengaruh nyata terhadap luas daun. Ratarata luas daun sawi hijau dapat dilihat pada Tabel 1. Luas daun terbaik diperoleh pada pemberian 15 ton ha ${ }^{-1}$ kompos TKKS +30 ton ha-1 kompos gedebok pisang dengan rata-rata $400.74 \mathrm{~cm}^{2}$ berbeda tidak nyata dengan luas daun pada pemberian 20 ton ha-1 kompos TKKS +20 ton ha-1 kompos gedebok pisang namun berbeda nyata dengan perlakuan lainnya. Luas daun terendah diperoleh pada perlakuan tanpa pemberian kompos dengan rata-rata $15.70 \mathrm{~cm}^{2}$ yang berbeda nyata dengan luas daun pada perlakuan lainnya. Penambahan kompos TKKS dan kompos gedebok pisang dalam tanah gambut diduga terdapat unsur yang dapat membantu proses fotosintesis, selanjutnya hasil fotosintesis dirombak melalui respirasi menghasilkan energi menyebabkan daun lebih panjang dan lebar sehingga luasnya bertambah. Unsur $\mathrm{N}$ bagi tanaman dapat mempercepat pembentukan klorofil daun, sehingga proses fotosintesis tanaman akan berjalan dengan maksimal dan membantu tanaman dalam memacu pertumbuhan vegetatif salah satunya yaitu pembentukan jumlah dan luas daun (Asra et al., 2015).

\section{Bobot Segar Tanaman}

Hasil analisis keragaman menunjukkan bahwa dosis interaksi kompos TKKS dan kompos gedebok pisang berpengaruh nyata terhadap bobot segar tanaman. Rata-rata bobot segar tanaman sawi hijau dapat dilihat pada Tabel 1. Bobot segar tanaman terbaik diperoleh pada pemberian 15 ton ha-1 kompos TKKS +30 ton ha $^{-1}$ kompos gedebok pisang dengan rata-rata $176.71 \mathrm{~g}$ berbeda nyata dengan bobot segar tanaman pada perlakuan lainnya, sedangkan bobot segar tanaman terendah yaitu pada perlakuan tanpa pemberian kompos dengan rata-rata $9.52 \mathrm{~g}$ berbeda nyata dengan bobot segar tanaman pada perlakuan lainnya. Pencapaian berat tanaman membutuhkan energi dan unsur hara yang banyak sehingga penambahan jumlah dan ukuran sel akan maksimal dengan penyerapan kandungan air yang optimal (Lahadassy et al., 2007).

Meningkatnya dosis kompos TKKS dan kompos gedebok pisang yang diaplikasilkan mampu meningkatkan bobot segar tanaman, hal ini sebabkan semakin tinggi dosis kompos yang diberikan suplai unsur hara bagi tanaman akan semakin meningkat sehingga proses metabolisme tanaman akan semakin maksimal. Sejalan dengan pendapat Roidah (2013) menyatakan pertumbuhan tanaman akan diikuti oleh meningkatnya berat segar tanaman dan daya ikat air dengan pemberian bahan organik sehingga kondisi tanah juga semakin membaik.

\section{Bobot Kering Tanaman}

Hasil analisis keragaman menunjukkan bahwa dosis interaksi kompos TKKS dan kompos gedebok pisang berpengaruh nyata terhadap bobot kering tanaman. Ratarata bobot kering tanaman sawi hijau dapat dilihat pada Tabel 1. Bobot kering tanaman sawi hijau terbaik diperolah pada pemberian 15 ton ha ${ }^{-1}$ kompos TKKS +30 ton ha ${ }^{-1}$ kompos gedebok pisang dengan rata-rata $16.80 \mathrm{~g}$ berbeda nyata dengan bobot kering tanaman pada perlakuan lainnya, sedangkan bobot kering tanaman terendah yaitu pada perlakuan tanpa pemberian kompos dengan rata-rata 1.09 $\mathrm{g}$ berbeda tidak nyata dengan bobot kering tanaman pada pemberian 5 ton $\mathrm{ha}^{-1}$ kompos TKKS +0 ton ha-1 kompos gedebok pisang dan berbeda nyata dengan perlakuan lainnya.

Pemberian kompos TKKS dan kompos gedebok pisang dapat memberikan hasil yang baik pada serapan unsur nitrogen di dalam tanah. Menurut Bass et al. (2016) bahan organik yang diaplikasikan sebagai pembenah tanah berpotensi dalam meningkatkan hasil tanaman dan memperbaiki kondisi tanah. Selain itu, dapat meningkatkan serapan hara di dalam tanah yaitu N, P, dan K (Maftua'ah et al., 2013). Tanaman memerlukan unsur hara untuk melakukan fotosintesis, semakin banyak unsur hara yang diserap tanaman maka akan semakin tinggi terjadinya proses fotosintesis dan hasil akumulasi fotosintat akan semakin besar yang diikuti dengan meningkatnya berat kering tanaman. Penelitian yang dilakukan Gusta et al. (2017) menunjukkan bahwa penggunaan media kompos dari sabut kelapa sawit sebagai media tanam nyata meningkatkan bobot kering pada pembibitan tanaman kelapa sawit.

\section{Laju Asimilasi Bersih}

Hasil analisis laju asimilasi bersih pada tanaman sawi hijau menunjukkan hasil terbaik pada minggu ke3, hal ini diduga adanya pengaruh kompos TKKS dan kompos gedebok pisang. Rata-rata laju asimilasi bersih tanaman sawi hijau pada pemberian berbagai dosis 
kombinasi kompos TKKS dan kompos gedebok pisang dapat dilihat pada Gambar 2. Laju asimilasi bersih yang diperoleh tidak konstan terhadap waktu pengamatan seiring dengan bertambahnya umur tanaman. Biomassa sawi hijau merupakan akumulasi fotosintat yang tersimpan di dalam batang dan daun. Menurut Wulandari et al. (2011) pupuk organik dari gedebok pisang dapat menjadi alternatif untuk dikembangkan karena banyak mengandung unsur hara yang diperlukan tanaman. Berdasarkan hasil analisis laboratorium terhadap kandungan kompos TKKS dan kompos gedebok pisang menunjukkan bahwa selain $\mathrm{pH}$ yang netral kompos TKKS dan kompos gedebok pisang memiliki kandungan unsur hara serta bakteri penambat $\mathrm{N}$ dan $\mathrm{P}$ yang baik sebagai sumber hara bagi tanaman yang dapat dilihat pada Tabel 2. Menurut Simbolon et al. (2018) perbaikan kualitas tanah serta mengurangi limbah pertanian dapat dilakukan dengan pemanfaatan tandan kosong kelapa sawit. Biomassa sawi hijau merupakan akumulasi fotosintat yang berada dibatang dan daun. Laju asimilasi bersih merupakan hasil bersih proses asimilasi persatuan luas daun dan waktu. Laju asimilasi bersih tidak konstan terhadap waktu tetapi mengalami penurunan dengan bertambahnya umur tanaman (Gardner et al., 1991).

\section{Laju Pertumbuhan Tanaman}

Hasil analisis terhadap laju pertumbuhan tanaman sawi hijau menunjukkan hasil terbaik pada pengamatan minggu ke-4. Rata-rata laju pertumbuhan tanaman sawi hijau pada pemberian berbagai dosis kombinasi kompos TKKS dan kompos gedebok pisang dapat dilihat pada Gambar 3. Hal ini diakibatkan oleh meningkatnya kandungan unsur hara di
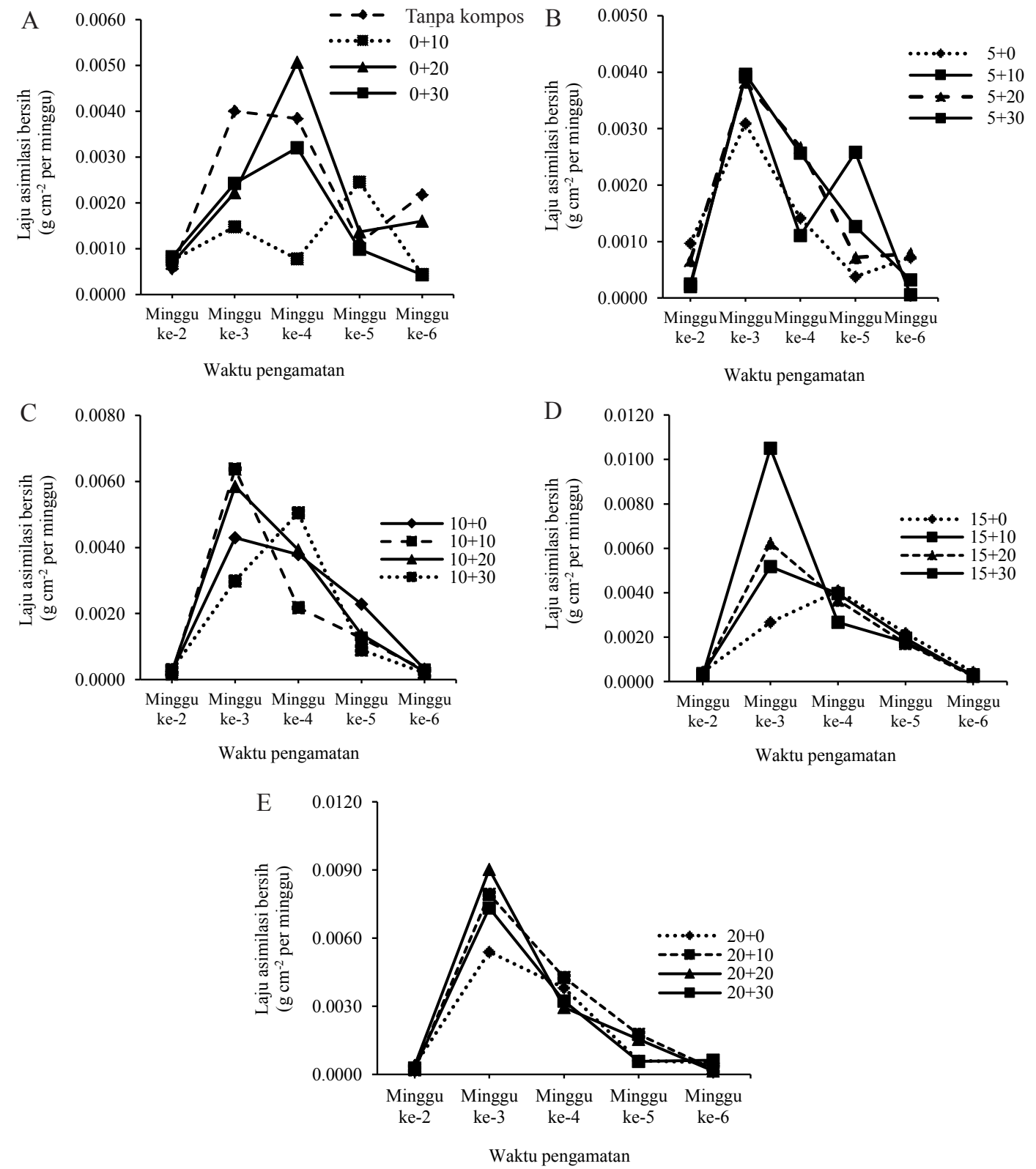

Gambar 2. Laju asimilasi bersih tanaman sawi hijau pada tanah gambut dengan pemberian berbagai dosis kompos TKKS: (A) $\mathrm{t}_{0}$ (tanpa kompos), (B) $t_{1}\left(5\right.$ ton $\left.h^{-1}\right)$, (C) $t_{2}\left(10\right.$ ton ha $\left.{ }^{-1}\right)$, (D) $t_{3}\left(15\right.$ ton ha $\left.{ }^{-1}\right),(E) t_{4}\left(20\right.$ ton ha $\left.{ }^{-1}\right)$, masing-masing pada 4 taraf dosis kompos gedebok pisang 
Tabel 2. Kandungan unsur hara dan bakteri penambat N dan P dari kompos TKKS dan kompos gedebok pisang

\begin{tabular}{lcc}
\hline Sifat kimia & Kompos TKKS & Kompos gedebok pisang \\
\hline $\mathrm{pH}$ & 6.15 & 8.48 \\
Carbon organik (\%) & 46.07 & 40.10 \\
Nitrogen total (\%) & 2.36 & 2.12 \\
$\mathrm{C} / \mathrm{N}$ rasio & 19.52 & 18.92 \\
Ekstraksi HCl 1N & & 0.50 \\
Fosfor (\%) & 0.27 & 0.63 \\
Kalium (\%) & 0.15 & 0.07 \\
Kalsium (\%) & 0.28 & 0.01 \\
Magnesium (\%) & 0.25 & $2 \times 10^{-3}$ \\
Bakteri penambat $\mathrm{N}\left(\mathrm{cfu} \mathrm{g}^{-1}\right)$ & $10 \times 10^{-3}$ & $5 \times 10^{-3}$ \\
Bakteri pelarut P $\left(\mathrm{cfu} \mathrm{g}^{-1}\right)$ & $8 \times 10^{-3}$ & \\
\hline
\end{tabular}
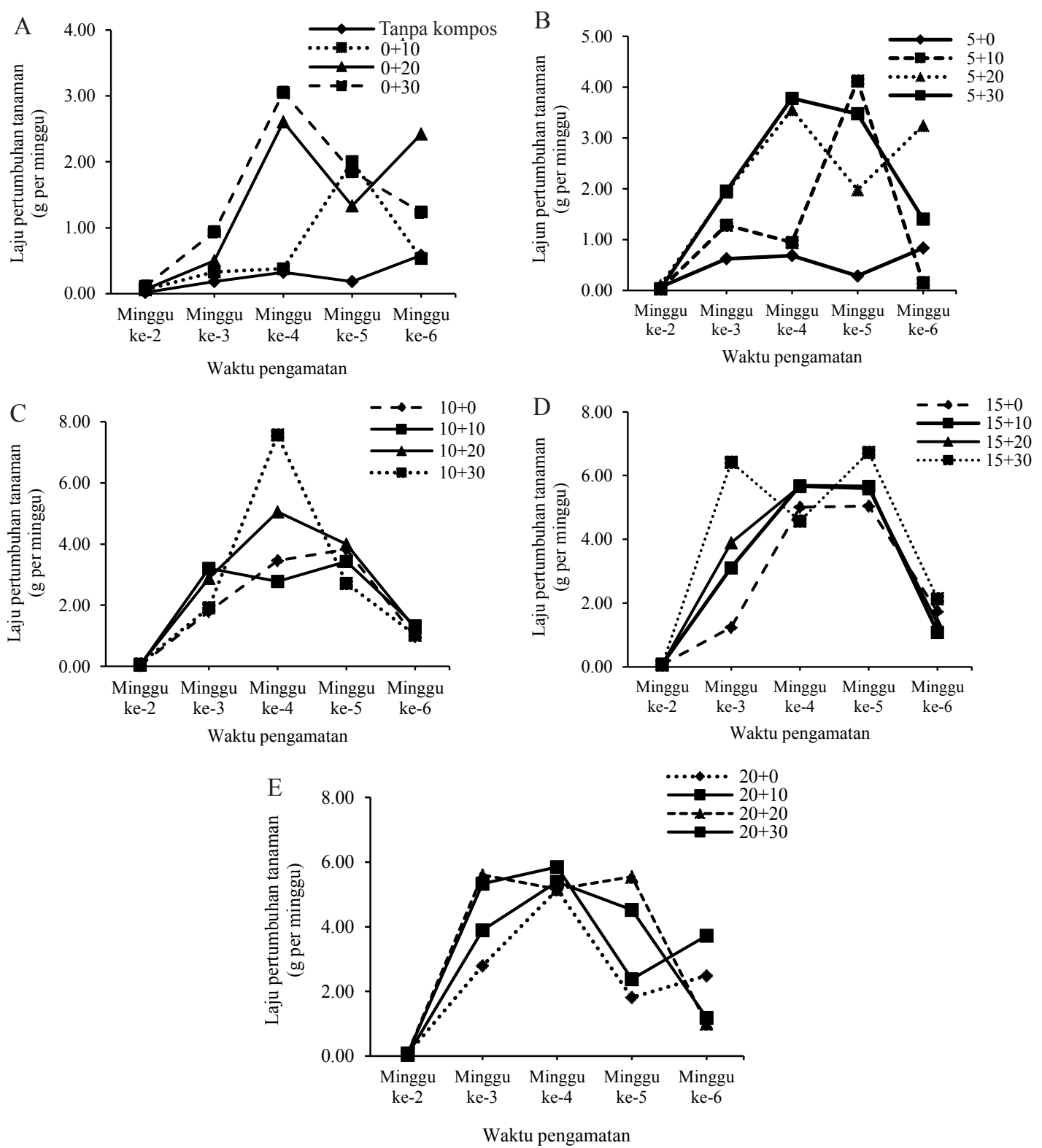

Gambar 3. Laju pertumbuhan tanaman sawi hijau pada tanah gambut dengan pemberian berbagai dosis kompos TKKS: (A) $t_{0}(\operatorname{tanpa}$ kompos), (B) $\mathrm{t}_{1}(5$ ton ha-1 $)$, (C) $\mathrm{t}_{2}\left(10\right.$ ton $\left.\mathrm{ha}^{-1}\right)$, (D) $\mathrm{t}_{3}\left(15\right.$ ton ha- $\left.{ }^{-1}\right)$, (E) $\mathrm{t}_{4}\left(20\right.$ ton ha $\left.{ }^{-1}\right)$, masing-masing pada 4 taraf dosis kompos gedebok pisang 
dalam tanah gambut akibat pemberian kompos TKKS dan kompos gedebok pisang sehingga mengakibatkan proses metabolisme tanaman berjalan secara maksimal sehingga proses pembelahan sel tanaman menjadi lebih maksimal. Laju pertumbuhan tanaman menunjukkan kemampuan untuk menghasilkan biomassa persatuan waktu. Menurut Rahmah (2014) adanya peningkatan biomassa dikarenakan tanaman menyerap air dan hara lebih banyak, unsur hara memacu perkembangan organ pada tanaman seperti akar, sehingga tanaman dapat menyerap hara dan air lebih banyak selanjutnya aktifitas fotosintesis akan meningkat dan mempengaruhi peningkatan berat basah dan berat kering tanaman.

Hasil analisis tanah gambut sebelum diinkubasi $\mathrm{N}$ 1.82\%; P 121.68 ppm; dan K $0.42 \mathrm{cmol}(+) \mathrm{kg}^{-1}$. Derajat kemasaman atau $\mathrm{pH} 3.77$ tidak memungkinkan tanaman dapat tumbuh maksimal. Kandungan unsur kimia setelah inkubasi media tanah gambut yang ditambah kompos TKKS dan kompos gedebok pisang mengalami peningkatan $\mathrm{N}$ total 2.80\%; $\mathrm{P}_{2} \mathrm{O}_{5} 620.45 \mathrm{ppm}$ dan $\mathrm{K} 11.80 \mathrm{cmol}(+) \mathrm{kg}^{-}$ ${ }^{1}$ dengan presentase peningkatan N 53.85\%; P 409.90\% dan K 2,709\%. Pemberian TKKS dan gedebok pisang dapat meningkatkan $\mathrm{pH}$ menjadi 6.13 sehingga unsur hara diperlukan tanaman tersedia.

Pemberian kompos TKKS dan gedebok pisang memberikan reaksi yang signifikan pada sawi hijau dan dapat terpenuhi tanpa penambahan pupuk anorganik. Menurut Priyadi et al. (2020) penggunaan bahan amelioran dan kompos dapat memperbaiki sifat-sifat tanah pasir. Secara biologi bahan organik yang diaplikasikan dapat mempengaruhi aktifitas organisme makroflora dan mikrofauna dan secara fisik yaitu dapat memperbaiki struktur tanah (Jenira et al., 2016). Menurut Tobing et al. (2014) peningkatan populasi bakteri dengan pemberian kompos menunjukkan hasil dekomposisi bahan organik mengandung $\mathrm{C}$ serta $\mathrm{N}$ organik yang dapat digunakan sebagai sumber nutrisi oleh mikroba yang dapat meningkatkan kesuburan.

\section{KESIMPULAN}

Dosis kompos TKKS dan kompos gedebok pisang terbaik dalam meningkatkan pertumbuhan dan hasil tanaman sawi hijau yaitu pada pemberian 15 ton ha ${ }^{-1}$ kompos TKKS yang dikombinasi dengan 30 ton $\mathrm{ha}^{-1}$ kompos gedebok pisang berdasarkan variabel tinggi tanaman, jumlah daun, luas daun, bobot segar tanaman, bobot kering tanaman, laju asimilasi bersih dan laju pertumbuhan tanaman. Hasil analisis tanah gambut sebelum diinkubasi $\mathrm{N} \mathrm{1.82 \%} ; \mathrm{P}_{2} \mathrm{O}_{5} 121.68$ ppm; K $0.42 \mathrm{cmol}^{(+)} \mathrm{kg}^{-1}$ dan $\mathrm{pH} 3.77$ sedangkan setelah inkubasi media tanah gambut ditambah 15 ton $\mathrm{ha}^{-1}$ kompos TKKS dan 30 ton ha $^{-1}$ kompos gedebok pisang mengalami peningkatan $\mathrm{N}$ total $2.80 \%, \mathrm{P}_{2} \mathrm{O}_{5} 620.45$ ppm, K 11.80 $\mathrm{cmol}^{(+)} \mathrm{kg}^{-1}$ dan $\mathrm{pH} 6.13$ dengan presentase peningkatan $\mathrm{N}$, P, dan K berturut-turut sebesar $53.85 \%$, 409.90\% dan $2.709 \%$.

\section{DAFTAR PUSTAKA}

Asra, G., T. Simanungkalit, N. Rahmawati. 2015. Respons pemberian kompos tandan kosong kelapa sawit dan zeolit terhadap pertumbuhan bibit kelapa sawit di prenursery. J. Agroekoteknologi 3:416-426.

Badan Pusat Statistik. 2018a. Kalimantan Barat dalam Angka. http://bps.go.id [20 Juni 2020].

Badan Pusat Statistik. 2018b. Statistik Pertanian Tanaman Sayuran dan Buah-Buahan Provinsi Kalimantan Barat Tahun 2018. http://bps.go.id [20 Juni 2020].

Bass, A.M., M.I. Bird, G. Kay, B. Muirhead. 2016. Soil properties, greenhouse gas emissions and crop yield under compost, biochar, and co-composted biochar in two tropical agronomic systems. J. Sci. Total. Environ. 550:459-470.

Direktorat Gizi Departemen Kesehatan RI. 2012. Komposisi Kimia Sawi Hijau. Depkes RI. Jakarta.

Fauzi, A., F. Puspita. 2017. Pemberian kompos TKKS dan pupuk P terhadap pertumbuhan bibit kelapa Sawit (Elaeis guineensis Jacq.) di pembibitan utama. J. Online 4:1-12.

Gardner, F.P., R.B. Pearce, R.L. Mitchell. 1991. Physiology of Crop Plants (Fisiologi Tanaman Budidaya, alih bahasa oleh Susilo, H.). Universitas Indonesia Press. Jakarta.

Gusta, A.R., A. Kusumastuti, Y. Parapasan. 2017. Pemanfaatan kompos kiambang dan sabut kelapa sawit sebagai media tanam alternatif pada prenursery kelapa sawit (Elaeis guineensis Jacq.). J. Penelit. Pertan.Terap. 15:151-155.

Hasanudin. 2003. Peningkatan ketersediaan dan serapan N dan P serta hasil tanaman jagung melalui inokulasi mikoriza, azobakter dan bahan organik pada ultisol. J. Ilmu Ilmu Pertanian Indonesia 5:83-89.

Jenira, H., Sumarjan, S. Armiani. 2016. Pengaruh kombinasi pupuk organik dan anorganik terhadap produksi kacang tanah (Arachis hypogaea L.) varietas lokal bima dalam upaya pembuatan brosur bagi masyarakat. Bioscientist. J. Ilmiah Biologi 5:1-12.

Lahadassy, J., A.M. Mulyanti, A.H. Sanaba. 2007. Pengaruh dosis pupuk organik padat daun gamal terhadap tanaman sawi. J. Agrisistem 3:80-85. 
Leonardo, A., E. Yulia, S. Indra. 2016. Pemberian kompos tandan kosong kelapa sawit dan mulsa helaian anak daun kelapa sawit pada medium tanam sub soil bibit kelapa sawit (Elaeis guineensis Jacq.) tahap main nursery. J. Online Mahasiswa Fakultas Pertanian Universitas Riau 3:1-14.

Maftu'ah, E., A. Maas, A. Syukur, B.H. Purwanto. 2013. Efektivitas amelioran pada lahan gambut terdegradasi untuk meningkatkan pertumbuhan dan serapan NPK tanaman jagung manis (Zea mays L. var. saccharata). J. Agron. Indonesia 41:16-23.

Pane, M.A., M.M.B. Damanik, B. Sitorus. 2014. Pemberian bahan organik kompos jerami dan abu sekam padi dalam memperbaiki sifat kimia tanah ultisol serta pertumbuhan tanaman jagung. J. Agroekoteknologi 2:1426-1432.

Priyadi, Jamaludin, W. Mangiring. 2020. Aplikasi kompos dan arang aktif sebagai bahan amelioran di tanah berpasir terhadap pertumbuhan tanaman caisim (Brassica juncea L.). J. Penelitian Pertanian Terapan 18:81-86.

Rahmah, A. 2014. Pengaruh Pupuk Organik Cair Berbahan Dasar Limbah Sawi Putih (Brassica Chinensis L.) Terhadap Pertumbuhan Tanaman Jagung Manis (Zea mays L. var. saccharata). Laporan Penelitian. Universitas Diponegoro. Semarang.
Riswandi. 2011. Kajian Stabilitas Gambut Tropika Indonesia Berdasarkan Analisis Kalangan Karbon Organik Sifat Fisik, Kimia dan Komposisi Bahan Gambut. Disertasi. Program Pasca Sarjana. Institut Pertanian Bogor. Bogor.

Roidah, I.S. 2013. Manfaat penggunaan pupuk organik untuk kesuburan tanah. J. Bonoworo 1:30-42.

Sari, V.I., Sudradjat, Sugiyanta. 2015. Peran pupuk organik dalam meningkatkan efektivitas pupuk NPK pada bibit kelapa sawit di pembibitan utama. J. Agron. Indonesia 43:153-160.

Simbolon, Y., B.W. Simanihuruk, B.G. Murcitro, H. Gusmara, E. Suprijono. 2018. Pengaruh subtitusi pupuk $\mathrm{N}$ sintetik dengan limbah lumpur sawit terhadap pertumbuhan dan hasil jagung manis. J. Ilmu-ilmu Pertanian Indonesia 20:51-59.

Tobing, S., N.R. Mubarik, Triadiati. 2014. Aplikasi Bradyrhizobium japonicum dan Aeromonas salmonicida pada penanaman kedelai di tanah asam dalam percobaan rumah kaca. J. Biotik 2:1-7.

Wulandari, S.A., I. Mansur, H. Sugianti. 2011. Pengaruh pemberian kompos batang pisang terhadap pertumbuhan semai jabon (Anthocephalus cadamba Miq.). J. Silvikultur Trop. 3:78-81. 